\title{
Short Term Fluctuations and Succession Trends in Tropical Floodplain Vegetation Measured by Correspondence Analysis
}

\author{
Anderson Medeiros dos Santos ${ }^{1,2^{*}}$ and Sidinei Magela Thomaz ${ }^{1}$ \\ ${ }^{1}$ Universidade Estadual de Maringá; Bloco G-90; NUPELIA; Av. Colombo, 5790; 87020-900; Maringá - PR - \\ Brasil. ${ }^{2}$ Departamento de Biologia Geral; Universidade Estadual de Montes Claros - CCBS; Rua Rui Braga; \\ Campus Darcy Ribeiro; anderson.santos@unimontes.br; 39401-089; Montes Claros - MG - Brasil
}

\begin{abstract}
The aim of this work was to study the aquatic macrophytes community development to distinguish the fluctuations from succession trends at different temporal and spatial scales in the Upper Paraná River floodplain. The samples were collected quarterly from May 2000 to March 2002 in seven lakes with different degrees of connectivity from the main river channel and analyzed by between-class correspondence analysis. It was difficult to establish any pattern of community development at local scale but at a higher level of organization, disconnected lakes were characterized by fluctuation of the floristic composition. Connected lakes showed a straight trajectory, indicating that succession was occurring at these sites. Probably the income of propagules and diaspores from the river into connected lakes was the driving force of the observed change in community composition.
\end{abstract}

Key words: Aquatic macrophytes, Correspondence Analysis, Paraná River, succession, tropical floodplain

\section{INTRODUCTION}

Succession implies a sequence of events in time or place. In the ecological literature, the term has mostly been used to denote the sequences of change on community attributes along ecological time scales. In the last few decades, definitions of succession tended to be broad, to exclude only the seasonal fluctuation and cyclic changes from the gamut of recognized vegetation changes (Miles, 1991). Grime (1979) defined succession as a progressive alteration in the structure and species composition of the vegetation. Finegan (1984) defined it as the directional change in species composition and vegetation physiognomy of a single site with time. The above definitions focused mainly on plant ecology for which most of the succession theories were developed based mainly on primary succession examples, i.e. the colonization of a recently formed habitat. But the secondary succession and the later stages of primary succession may just reflect changing patterns of dominance by species present through most or all of the succession period as minor components or as propagules (Miles, 1991). Gleason's (1927) definition of succession is very

\footnotetext{
Author for correspondence
} 
broad including all types of change in time, either they are merely fluctuating or produce a fundamental change in the plant association. Although the distinctions are sometimes arbitrary, fluctuation and regeneration (which is cyclic) can commonly and usefully be distinguished from directional change, i.e., succession (Miles, 1979). Most of the literature regarding the plant succession deals with terrestrial plants in abandoned fields where succession leads to a predictable way. Data of wetland vegetation have detected multiple directions of change (Londo, 1974) and showed retrogressive trends to some extent. van der Valk (1981) had developed an allogenic qualitative model of vegetation dynamics in wetlands based on Gleason's broad idea of succession. In this model, succession occurs whenever one or more new species become established, when one or more species already present is extirpated, or when both events (establishment and extirpation) occur simultaneously in a wetland, and can predict changes in the composition of wetland vegetation by identifying a limited number of key life history features of wetland species. Regardless of the plant strategies (Grime C-R-S model, 1977), an important determinant of the course of any succession, and the prime determinant of secondary succession, is the range of species present at the outset and migrating to the site early in succession (Miles, 1991).

Tropical floodplains encompass a wide hydrological spectrum from short to long-duration floods, unpredictable to predictable timing (Junk et al., 1989; Neiff, 1990). The high diversity of temporary habitats can be associated to the insufficient time to allow competitive exclusion (Thomaz et al., 2007), according to the intermediate disturbance hypothesis (Connell, 1978). Many of the most persistent and productive tropical aquatic weeds (e.g., Eichhornia crassipes, Salvinia auriculata) are original from Neotropical river-floodplains systems, which are periodically decimated during the flood phase, allowing coexistence of many plant species with similar habitat requirements (Junk et al., 1989). In low water period, the oxbow-lakes remain isolated and the area covered by macrophytes is enlarged. Large amounts of nutrients are released from the sediments and an immediate increase in phytoplanktonic primary production coupled with water hyacinth growing season occurs. The cycle is interrupted by inflow of oxygenated water in the summer flood with the subsequent export of macrophytes to the main channel as observed, for example, in the Paraná River by Bonetto et al. (1984). In hydrologically stable conditions, aquatic weeds become dominant due to their strong competitive ability (Junk et al., 1989). Thus, ecological succession of floodplain vegetation is expected to be cyclic because floods resets succession to early initial stages (van der Valk, 1981; Junk and Piedade, 1997).

In Brazil, most of the hydrographic basin of the Upper Paraná River is under control by the dams, especially in the rivers of the left margin (Grande, Tietê and Paranapanema). The downstream flow regulation by the dams has resulted in serious deteriorations in river-floodplain ecosystems by flattening of the flood pulses and reducing the connectivity between the main river channel and the floodplain habitats (Amoros, 1991; Agostinho et al., 2000).

The present study investigated different temporal and spatial scales to distinguish fluctuations (i.e., only quantitative changes in the abundance of species) from successional trends (i.e., qualitative changes in the species composition) of aquatic macrophytes assemblages in lakes with different degrees of connectivity with two rivers that drained into the Upper Paraná River floodplain. The hypothesis to be tested was that succession would occur in connected lakes due to permanent income of propagules and seeds from main river whereas fluctuations would occur only in disconnected lakes.

\section{Study Area}

The samples were collected quarterly (from May 2000 to March 2002) in seven lakes close to Baía and Ivinheima rivers in the Upper Paraná River floodplain, located downstream from Porto Primavera Reservoir (Fig.1). The lakes differed according to their degree of connectivity in permanently connected (lakes: Onça, Patos, Boca do Ipoitã and Finado Raimundo) and disconnected (Zé do Paco, Traíra and Ventura) with the main channel.

The environments were quite heterogeneous, both spatially and temporally regarding their abiotic conditions. A wide survey in several lakes of this floodplain showed values of electric conductivity from 16 to $107 \mu{\mathrm{S} . \mathrm{cm}^{-1}}^{-}$pH from 4.0 to 9.1 ; totalP from 9 to $180 \mu \mathrm{g} . \mathrm{L}^{-1}$ and of Kjeldahl-N from 0 to $2,590 \mu \mathrm{g} \cdot \mathrm{L}^{-1}$. Other details about the limnologic 
features of those environments can be found in Thomaz et al. (2004).

\section{MATERIALS AND METHODS}

In each lake, a permanent transect from the margin to the pelagic region was positioned in the stand. The stands with more species of aquatic macrophytes observed in each lake were selected. They also represented well developed stands, i.e., the longest occupation was found in the lake. In the Patos and Boca do Ipoitã lakes, two transects were used due to their larger areas. The depth and the covering of each species of aquatic macrophyte were recorded in a $0.5 \times 0.5 \mathrm{~m}$ quadrat along transect at every $2 \mathrm{~m}$, based on the Domin-Krajina cover scale $(1=<20 \% ; 2=21$ $40 \% ; 3=41-60 \% ; 4=61-80 \% ; 5=81-100 \%$ of covering). Thus, the number of quadrats in each transect depended on the length of the aquatic macrophytes stand. The number of quadrats varied from 0 (no species presence) to 25 . The distance from the margin to each quadrat was also measured and the data (distance and depth) were used to estimate the littoral slope for each transect in each sampling period.

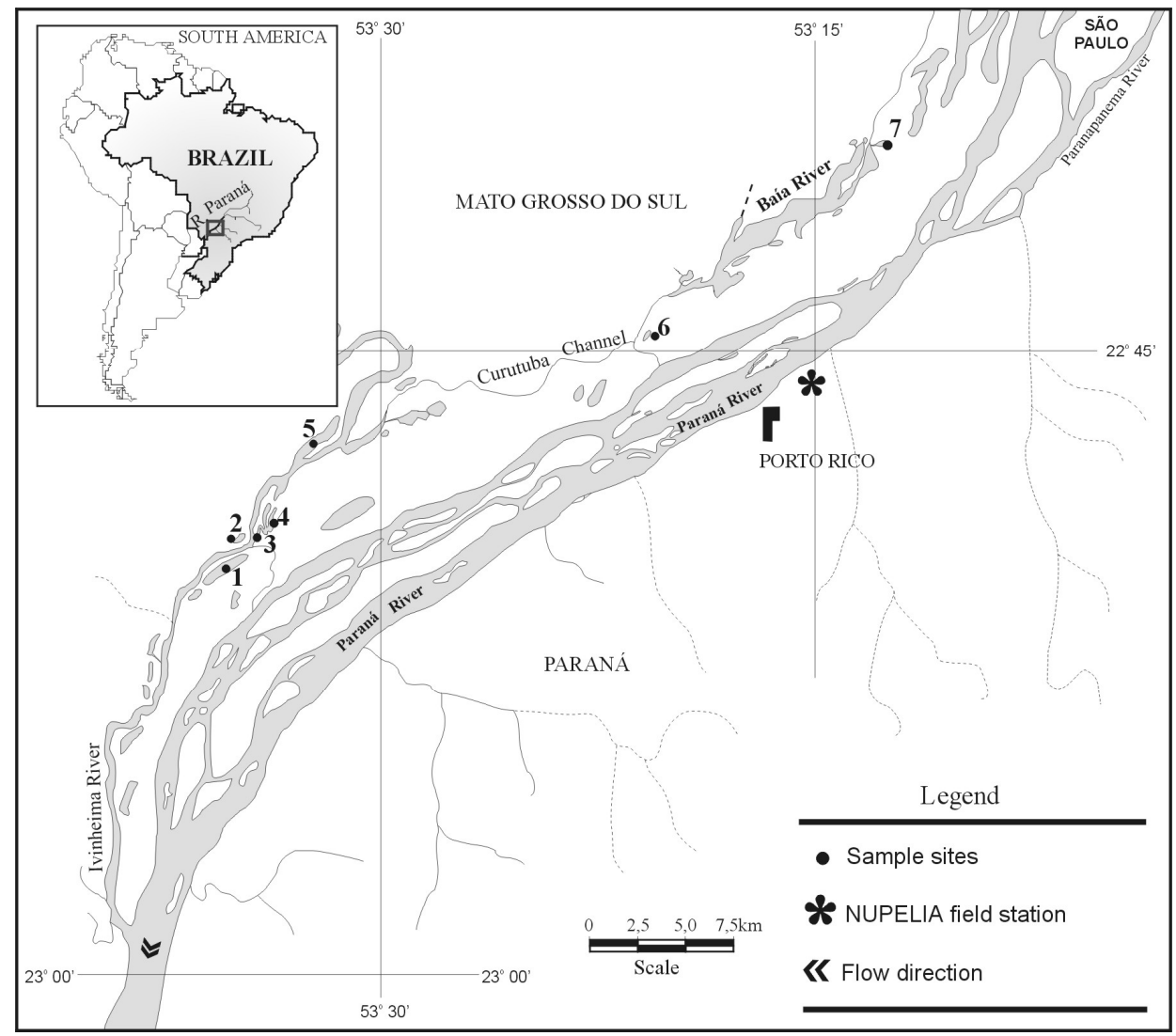

Figure 1 - Map with the localization of sampled sites with the respective codes. 1- Ventura Lake, 2- Zé do Paco Lake, 3- Boca do Ipoitã Lake, 4- Patos Lake, 5- Finado Raimundo Lake, 6- Traíra Lake and 7- Onça Lake. NUPELIA (Núcleo de Pesquisas em Limnologia Ictiologia e Aquicultura).

The floristic data matrix was analyzed using between-classes correspondence analysis (CA) (Bornette et al., 1994a). In the between-classes $\mathrm{CA}$, data were averaged per class and the reduced matrix was analyzed using simple CA. Thus, the original data could be plotted on the CA diagram and one could look for fluctuations around the average positions of classes. This method focused on the mean influences of classes considered and three classes were investigated at different scales: (i) interannual-site class; (ii) seasonal-connectivity class and; (iii) interannual-connectivity class. The 
scores of CA seasonal-connectivity classes were regressed against the depth in order to study its influence on the macrophyte assemblage structures. The following species were eliminated from the analysis due to their low occurrence (less than two times): Bacopa sp., Bulbostylis sp., Commelina sp., Egeria najas, Eleocharis sp., Echinodorus sp., Rhabdadenia pohlii and Wolffiella oblonga.

Table 1 - Species list of aquatic macrophytes, growth form and codes used in ordination analysis.

\begin{tabular}{|c|c|c|c|}
\hline Species & Family & Code & Growth form \\
\hline Azolla sp. & Azollaceae & Azol & Floating \\
\hline Bacopa sp. & Scrophulariaceae & Baco & Rooted Floating leaves \\
\hline Bulbostylis sp. & Cyperaceae & Bulb & Emergent \\
\hline Commelina sp. & Commelinaceae & Comm & Emergent \\
\hline Cyclanthera hystrix & Curcubitaceae & Chys & Emergent \\
\hline Echinodorus sp. & Alismataceae & Echi & Emergent \\
\hline Egeria najas & Hydrocharitaceae & Enaj & Submerged \\
\hline Eichhornia azurea & Pontederiaceae & Eazu & Rooted Floating leaves \\
\hline E. crassipes & Pontederiaceae & Ecra & Floating \\
\hline Eleocharis sp. & Cyperaceae & Eleo & Emergent \\
\hline Gramineae & Poaceae & Gram & Floating \\
\hline Hydrocotyle ranunculoides & Apiaceae & Hran & Floating \\
\hline Lemna sp. & Lemnaceae & Lemn & Floating \\
\hline Limnobium laevigatum & Hydrocharitaceae & Llae & Floating \\
\hline Ludwigia sp. & Onagraceae & Ludw & Emergent \\
\hline Nymphaea amazonum & Nymphaeaceae & Nama & Rooted Floating leaves \\
\hline Oxycaryum cubense & Cyperaceae & Ocub & Emergent \\
\hline Paspalum repens & Poaceae & Prep & Floating \\
\hline Pistia stratiotes & Aracceae & Pstr & Floating \\
\hline Polygonum acuminatum & Polygonaceae & Pacu & Emergent \\
\hline P. ferrugineum & Polygonaceae & Pfer & Emergent \\
\hline P. punctatum & Polygonaceae & Ppun & Emergent \\
\hline P. stelligerum & Polygonaceae & Pste & Emergent \\
\hline P.meissnerianum & Polygonaceae & Pmei & Emergent \\
\hline Rhabdadenia pohlii & Apocynaceae & Rpoh & Emergent \\
\hline Ricciocarpus natans & Ricciaceae & Rnat & Floating \\
\hline Salvinia spp. & Salvinaceae & Salv & Floating \\
\hline Utricularia foliosa & Lentibulariaceae & Ufol & Submerged \\
\hline Wolffiella oblonga & Lemnaceae & Wobl & Floating \\
\hline
\end{tabular}

\section{RESULTS}

Twenty nine species of aquatic macrophytes were registered in 19 families (Table 1). During the study period, an atypical decrease of the water level was observed in August/2001 (Fig. 2a). The damming of Porto Primavera Reservoir contributed to the reduction of the discharge of the Paraná River in this period (Souza Filho et al., 2004). However, the water level decrease could not be attributed exclusively to this fact, because low pluviometric indexes (a period of abnormal drought) were also observed in the same period all over the country. The depth varied from $0.65 \mathrm{~m}$, in August 2001 to $2.7 \mathrm{~m}$ in March of 2002. Both the depth $(\mathrm{F}=5.03 ; p=0.028)$ and the littoral slope $(\mathrm{F}$ $=6.67 ; p=0.012)$ were significantly different in connected and disconnected lakes (Fig. 2b).

\section{Interannual-site class}

Figure 3a shows the interannual-site (2000, 2001 and 2002) variation in aquatic macrophyte community composition by between-class CA 
(each year of each site represented a class). The beginning of the arrow indicates the year of 2000 and the head of the arrow indicates the year of 2002. Two types of trajectories were exhibited on CA factorial plane: (i) almost straight trajectory and; (ii) V-shape trajectory. The straight trajectories were observed for the connected lakes Ipoitã-1, Ipoitã-2 and Onça, and for the disconnected lakes Traíra and Ventura. All of these pointed at the same direction (positive scores of CA F1 axis), except for Ipoitã-2, which pointed to negative scores of CA F1 axis and had a slight modification of community composition from 2001 to 2002. Ipoitã-1 was characterized by a substitution of Eichhornia azurea by E. crassipes and an increase in abundance of Nymphaea amazonum between 2000 and 2002 (Fig. 3b). The same modifications also occurred in Ventura lake for the genus Eichhornia, a decrease in abundance of Salvinia spp. and an increase of Pistia stratiotes was recorded. This straight trajectory also indicated the decrease in the number of species, from 10 species in 2000 to 5 species at 2002 in this lake. The macrophyte community of Traíra lake changed from the absent of a Gramineae and Polygonum meissnerianum, the decrease of E. crassipes and an increase in abundance of Utricularia foliosa, from 2000 to 2002. Onça lake was the only site where the straight trajectory was characterized by an increase in the number of species, from 10 in 2000 to 14 in 2002. This modifications were followed by the decrease in abundance of E. azurea, E. crassipes and Salvinia spp., an increase in abundance of N. amazonum, Ludwigia sp. and U. foliosa and the occurrence of Azolla sp., Hydrocotyle ranunculoides, Paspalum repens and Limnobium laevigatum in 2002.

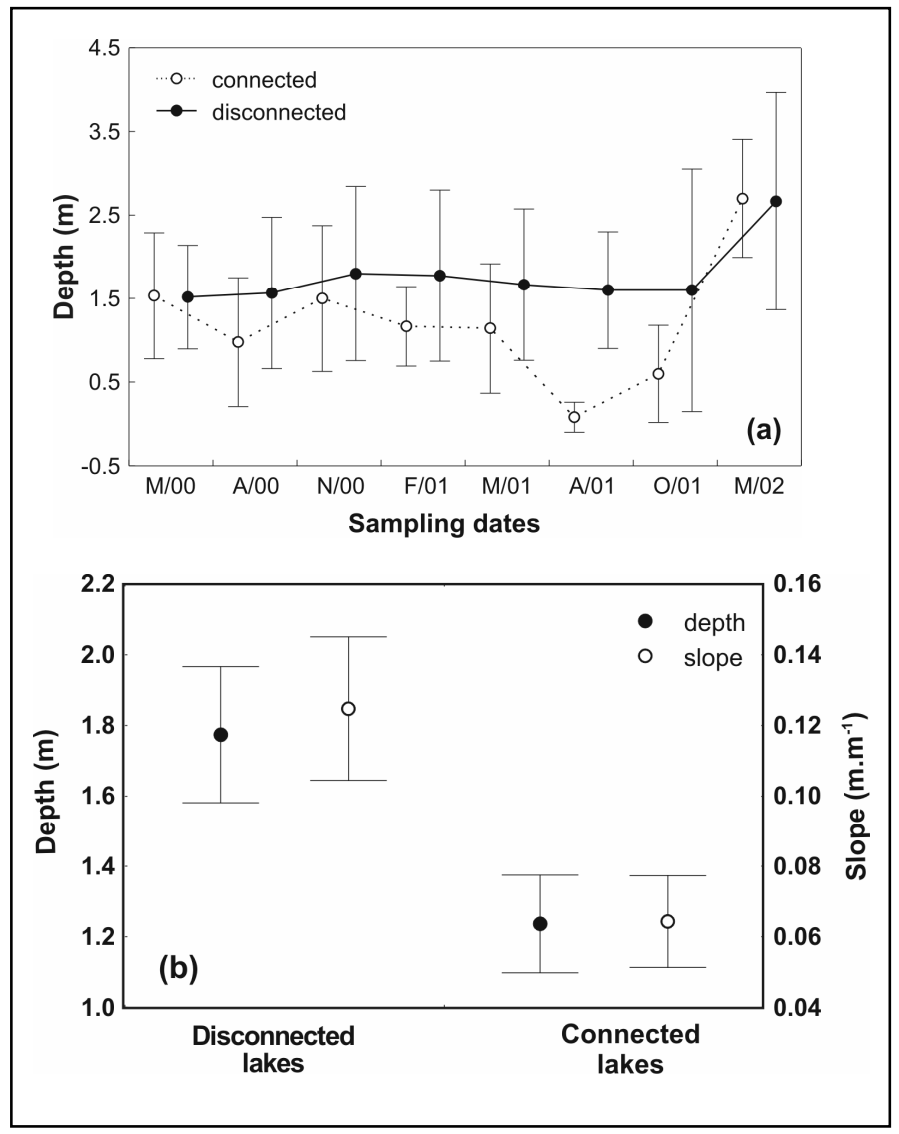

Figure 2 - (a) Average water level fluctuation in connected and disconnected lakes during sampling periods (May, August and November of 2000; February, May, August and October of 2001 and March of 2002) and; (b) difference in depth and littoral slope between connected and disconnected lakes. 


\section{Seasonal-connectivity class}

Figure 4 shows the floristic composition of connected and disconnected lakes by betweenclass CA (in this case, each date and degree of connectivity corresponds to a class). The V-shape trajectory of disconnected lakes occurred mainly on the orientation of the F1 axis (Fig. 4a), indicating a high variability in the community composition among sampling dates. The largest change was observed between November 2000 and February 2001 with a community shift from $E$. azurea and Salvinia spp. to the emergent species
$P$. ferrugineum (Fig. 4b). Moreover, there was a decrease in the total number of species, from 16 in November/2000 to six species in February 2001. The second largest change on disconnected lakes occurred between the driest period (August/2001), with $P$. ferrugineum as the main species, and October 2001, characterized by Salvinia spp. and O. cubense. Gramineae, Lemna sp. and Ricciocarpus natans were not observed in disconnected lakes at the end of the sampling period.

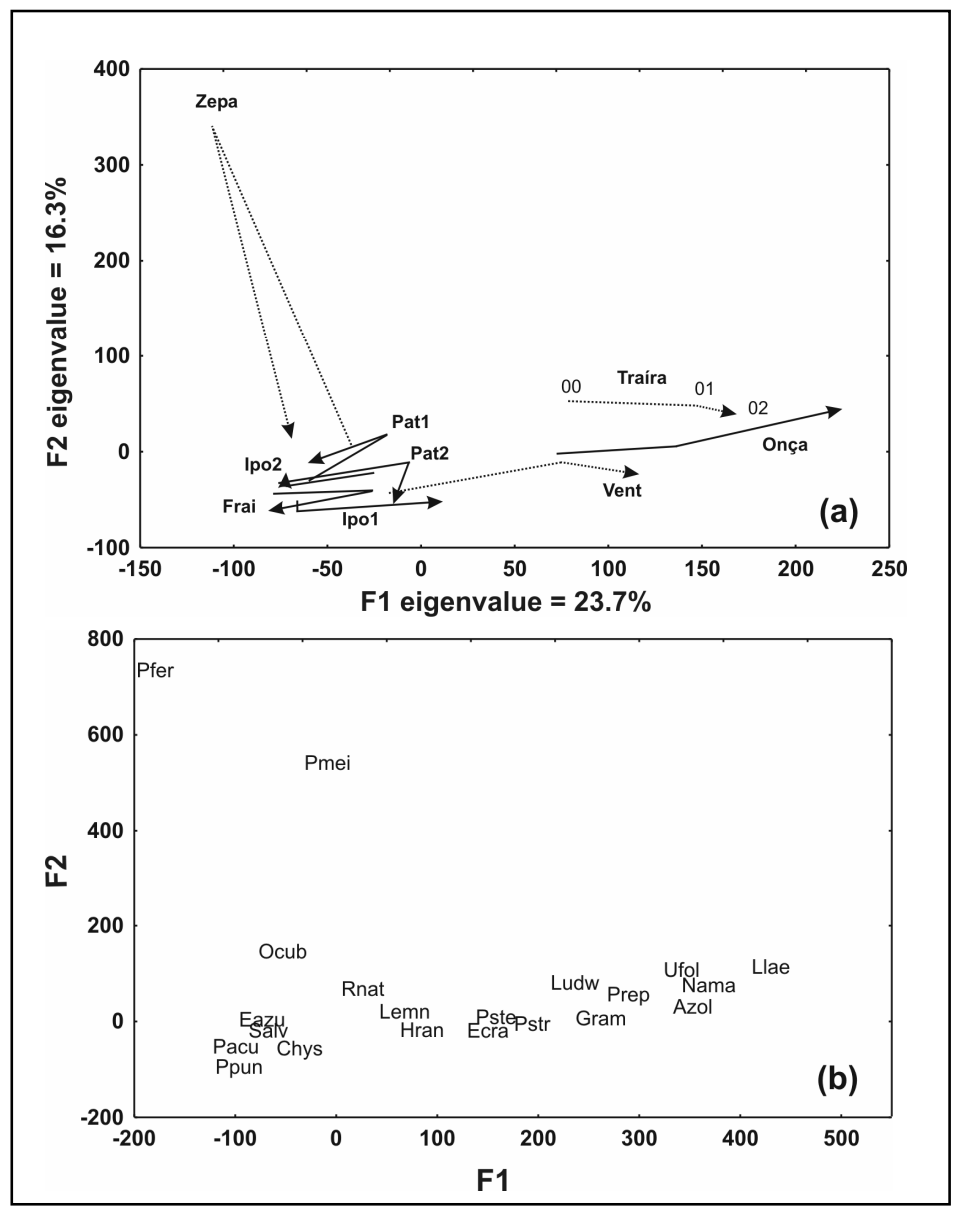

Figure 3 - Temporal changes of sampled sites at interannual-site scale analyzed by between-class correspondence analysis (each year of each site represents a class). (a) F1xF2 factorial plane of the classes (the beginning of the arrow indicates the year of 2000, the middle point indicate 2001 and the head of the arrow indicates the year of 2002, which are not completely showed in the map for a better visualization - the years are showed just for Traíra lake as example). Lakes codes: Ventura Lake (Vent), Zé do Paco Lake (Zepa), Boca do Ipoitã Lake (Ipo), Patos Lake (Pat), Finado Raimundo Lake (Frai), Traíra Lake (Traira) and Onça Lake (Onça). (b) F1xF2 factorial plane of the species. 


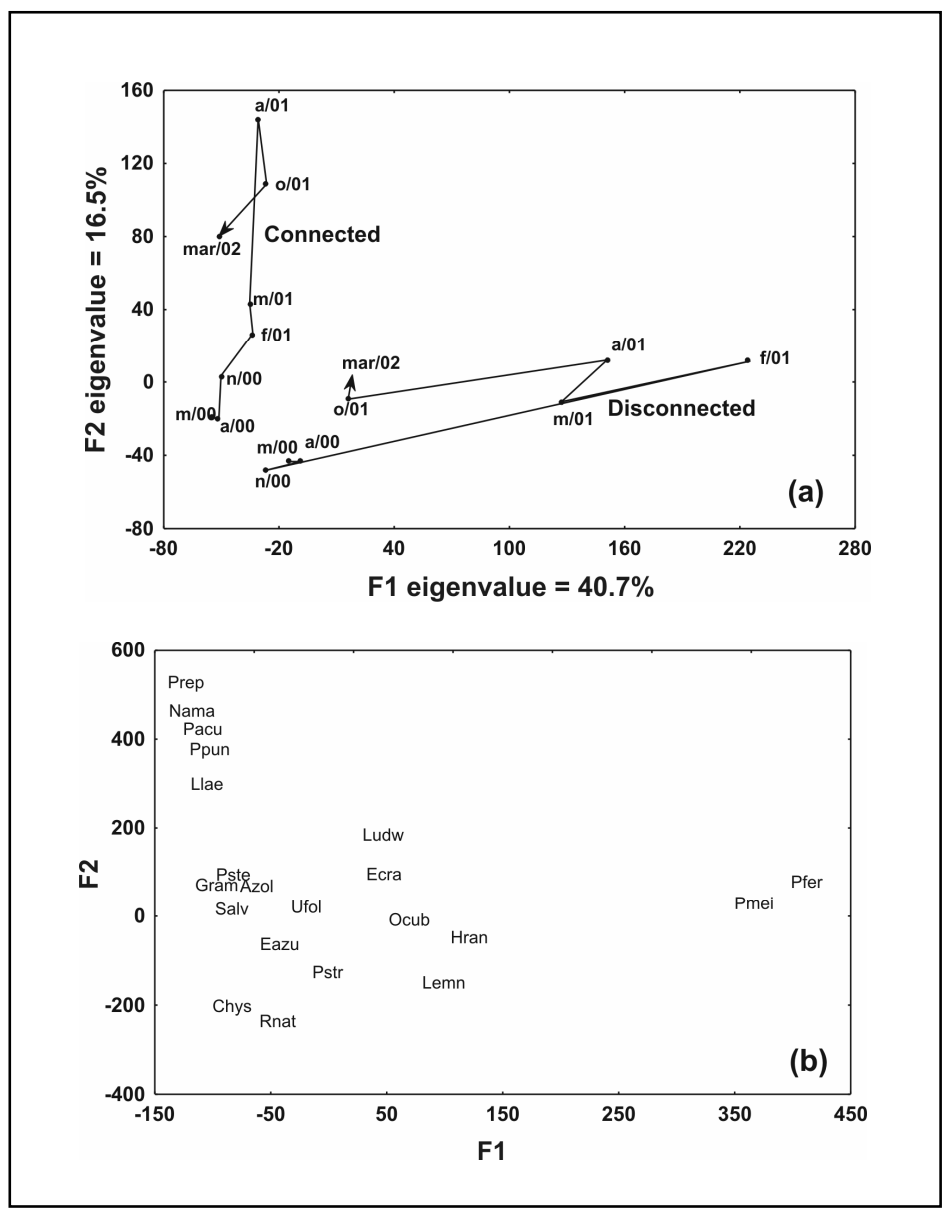

Figure 4 - Temporal changes of sampled sites at seasonal-connectivity scale analyzed by betweenclass correspondence analysis (each sampling date of each degree of connectivity represents a class). (a) F1xF2 factorial plane of the classes (m/00, a/00 and n/00 are respectively May, August and November of 2000; f/01, m/01, a/01 and o/01 are respectively February, May, August and October of 2001; mar/02 represents March of 2002). (b) F1xF2 factorial plane of the species.

The trajectory of connected lakes occurred along F2 axis orientation, indicating a smaller variation in the floristic composition among the sampling classes, compared to disconnected lakes. The largest change occurred between May and August 2001, characterized by 11 species and high abundances of E. azurea and Salvinia spp., which were drastically reduced, together with the number of species (7) in August 2001, the driest period. After that, the trajectory continued in a straight trajectory but in a reverse way, towards negative values of $\mathrm{F} 2$ axis, characterized by the appearance of $R$. natans, $P$. repens, $H$. ranunculoides; the reappearance of Azolla sp., L. laevigatum, $P$. stratiotes, $N$. amazonum, $P$. ferrugineum, $U$. foliosa, and increase in abundance of $P$. acuminatum, Salvinia spp. and $O$. cubense. This reversion towards an assemblage composed by free-floating species occurred concomitantly with the increase in water depth (see Fig. 2).

\section{Interannual-connectivity class}

In the interannual-connectivity class (Fig. 5), the trajectories of the connected and disconnected lakes were almost the same as exhibited by the seasonal-connectivity class (here, each coordinate in the factorial plane represented all the sites of a class of connectivity in each year). Because it was averaged by year, the fluctuation observed in the years in the seasonal-connectivity class plane were eliminated, and thus, a more stable pattern of the trajectories could be observed. Nevertheless, the 
clear differences between the connected and disconnected lakes were maintained. The largest change in community composition occurred from 2000 to 2001, the year of the extreme drought in both the connected and disconnected sites, and was characterized by a decrease in abundance of $E$. azurea and Salvinia spp., the dominant species.

Figure 5 - Temporal changes of sampled sites at interannual-connectivity scale analyzed by between-class correspondence analysis (each year of each degree of connectivity represents a class). (a) F1xF2 factorial plane of the classes (C: connected lagoons; D: disconnected lagoons; 00: 2000; 01: 2001; 02: 2002). (b) F1xF2 factorial plane of the species.

The modifications from 2000 to 2001 towards the positive scores of $\mathrm{F} 1$ axis in disconnected lakes were related to $P$. ferrugineum and $P$. meissnerianum, which indicated the terrestrialization. When water level increased in 2002, the main species were the free-floating $P$. stratiotes and E. crassipes. The total number of species was also reduced from 18 species in 2000 , 12 species in 2001 to eight species in 2002.

The straight trajectory towards the positive scores of F2 axis of connected lakes was related to the decrease in abundance of $P$. stelligerum, and an increase in the number of different biotypes of macrophytes [increase in abundance of Azolla sp. 
and L. laevigatum (free-floating); N. amazonum (floating leaves); P. acuminatum (emergent) and $U$. foliosa (submerged) and the occurrence of $P$. repens (emergent)]. The total number of species increased from 13 species in 2000 to 17 species in 2001 and 2002.

\section{DISCUSSION}

The two distinguished shapes of the trajectories of connected and disconnected lakes are related to different ways of community development due to water level fluctuations. Bornette et al. (1994a), studying changes in the aquatic macrophyte community in the Rhône River reported that Vshape trajectories could be interpreted as fluctuations on succession patterns. The magnitude of the changes in the community of connected (Pat-1, Pat-2 and Frai) and disconnected (Zepa) lakes between 2000 and 2001 were almost of the same order as the changes between 2001 and 2002, but occurred in a reverse way. According to the same authors, "Linear trajectories" (connected: Ipo-1, Ipo-2 and Onça; disconnected: Vent and Trai) could be interpreted as a shift in community composition, i.e., a succession trend.

Despite this interpretation, when a macro-scale was considered, it was clear that the level of organization (scale) influenced the interpretation of the observed patterns of succession and fluctuation in tropical floodplain lakes. At a local scale (interannual-site class - Fig. 3), connected and disconnected lakes had both straight and vshape trajectories suggesting that both fluctuations and succession trend had occurred in these sites. But one primary aspect of ecological succession was the increase in the number of species as well as the increase in the biological forms as time went by. By this way, the only sites that had an increase in the number of species were Onça, Ventura and Traíra lakes (straight trajectory) and Zé-do-Paco (v-shape), and thus, the trajectories of the CA factorial plane at this scale failed to distinguish the fluctuations from ecological succession and could not be used. Thus, even in a micro-system, marginal lakes had both succession trends and cyclic fluctuations occurring at the same time, which contributed to a high beta diversity of the Upper Paraná River floodplain.

At the seasonal-connectivity class scale, the differences between the connected and disconnected lakes and difference in $\mathrm{v}$-shape and straight trajectories became more evident. The floristic composition of connected lakes was clearly different form disconnected ones (Fig. 4). The stability of water level in the disconnected lakes moved community composition form most common and dominant species (Eichhonia azurea, Salvinia spp.) to $P$. ferrugineum and $P$. meissmerianum, which were species characteristic of dry environments. The number of species increased from nine species in May 2000 to 16 in November 2000 and decreased again to eight species at the end of the sampling period. At this scale, the V-shape trajectory was a good descriptor of the community composition and detected correctly the fluctuation of the community. The absence of communication with main river channel inhibited the income of other plant species different from the local pool, which was another indicative of "fluctuation" instead of "succession". The high variability in the community composition observed during the drought in the disconnected lakes suggested that these habitats were the first ones and the most affected by the water level control of the Paraná River.

Modification of the community composition of connected lakes occurred more slowly and less abruptly than in disconnected ones. It moves towards positive values of F2 axis with species that indicated terrestrialization (e.g., P. repens, P.acuminatum, $P$. punctatum) and species characteristic of flooded habitats (e.g., $N$. amazonum and a free-floating L. laevigatum) as the depth decreased to the minimum value observed during the study period (August 2001).

When water level increased, there was a move back toward negative scores of F2 axis but with less magnitude of change. In fact, the succession trend detected by the straight trajectory of connected lakes could be attributed to the exchange of materials as well as propagules and diaspores of other macrophyte species between the connected lakes and the main river channel, allowing new species to reach and occupying the new available habitat and increasing the local pool of species.

The dominant species in both the connected and disconnected lakes before drawdown were Salvinia spp., Eichhornia crassipes, E. azurea and Oxycaryum cubense, which was always associated with Salvinia spp. (O. cubense grows over Salvinia spp), indicating secondary succession (Pott and Pott, 2000). The genus Eichhornia and Salvinia are endemic to the Neotropical river-floodplains systems (Junk et al., 1989), having high rates of 
biomass production and are potential nuisance to water uses (Bini et al., 1999). Fortney et al. (2004) also reported the dominance of Salvinia auriculata and Eichhornia azurea in aquatic macrophytes in the Pantanal, a $140,000 \mathrm{~km}^{2}$ floodplain in westcentral Brazil. In our work, the drawdown period disrupted the Salvinia-Eichhornia dominance, allowing the coexistence of other species with similar habitat requirements in the flooded period (e.g., Pistia, Lemna, Wolfiela and Ricciocarpus) as reported by Junk et al. (1989) in the Amazonian floodplain.

At a higher level of organization (Interannualconnectivity class scale), the distinctions between the fluctuation of community composition from successional trends by $\mathrm{v}$-shape and straight trajectories respectively, became even more evident with higher percentage of explanation of F1 axis (see Figs. 3a, 4a and 5a). One important aspect was that if succession occurred, it was expected that the aquatic vegetation evolved toward emergent vegetation, as it was noted by the dominance of Polygonum when depth decreased (D-01). Bornette et al. (1994b), studying succession rates in six cut-off channels at Rhône River, found that emergent vegetation was associated with late succession stages, silt clay and organic mud substrate and eutrophic waters. But the community modification continued to move back to the center of the factorial plane in the flooded period (D-02) with the occurrence of other biological types characterizing a community fluctuation. On the other hand, the community composition of connected lakes at interannualconnectivity class of 2000 was completely different from 2002 and the increase in the number of species (13 to 17) during this period were a strong indicative that short term succession had occurred in these lakes.

\section{ACKNOWLEDGEMENTS}

We thanks the colleagues of NUPELIA (Núcleo de Pesquisas em Limnologia Ictiologia e Aquicultura) - Universidade Estadual de Maringá for all field assistant. This study was founded by $\mathrm{CNPq}$ and CAPES.

\section{RESUMO}

Trabalhos sobre sucessão ecológica foram realizados principalmente com ecologia vegetal de plantas terrestres, onde a maioria das teorias foram concebidas. Poucos estudos abordam a vegetação de áreas alagáveis especialmente no Brasil. Este trabalho investigou o desenvolvimento da comunidade de macrófitas aquáticas tentando distinguir flutuações populacionais de tendências sucessionais em diferentes escalas temporal e espacial na planície de inundação do Alto Rio Paraná. As amostras foram coletadas a cada três meses, de maio de 2000 a março de 2002, em 7 lagoas com diferentes graus de conectividade com a calha principal dos rios, e analisadas pela análise de correspondência (CA) entre-classes. Foi difícil estabelecer qualquer padrão de desenvolvimento da comunidade sob uma escala local, mas em uma escala mais ampla, as lagoas desconectadas foram caracterizadas pela flutuação da composição florística. As lagoas conectadas apresentaram uma trajetória retilínea no diagrama da CA, indicando que a sucessão estava ocorrendo nestes locais. Provavelmente, o aporte de propágulos e diásporos para as lagoas conectadas vindos do rio é a causa da alteração na composição da comunidade.

\section{REFERENCES}

Agostinho, A. A.; Thomaz, S. M.; Minte-Vera, C. V. and Winemiller, K. O. (2000), Biodiversity in the high Paraná River floodplain. In: Gopal, B.; Junk, W. J. and Davis, J. A. (Eds.). Biodiversity in Wetlands: Assessment, Function and Conservation. Backhuys, Leiden. pp. 89-118.

Amoros, C. (1991), Changes in side-arm connectivity and implications for river systems management. Rivers 2, 105-12.

Bini, L. M.; Thomaz, S. M.; Murphy, K. J. and Camargo, A. F. M. (1999), Aquatic macrophyte distribution in relation to water and sediment conditions in the Itaipu Reservoir, Brazil. Hydrobiologia 415, 147-54.

Bonetto, C. A.; Zalocar, Y. and Lancelle, H. G. (1984), A limnological study of an oxbow-lake covered by Eichhornia crassipes in the Paraná River. Verh. Internat. Verein. Limnol. 22, 1315-1318.

Bornette G.; Amoros C.; Castella C. and Beffy J. L. (1994a), Succession and fluctuation in the aquatic vegetation of two former Rhône River channels. Vegetatio, 110, 171-84. 
Bornette, G.; Amoros, C. and Chessel, D. (1994b), Effect of allogenic processes on successional rates in former river channels. J. Veg. Sci., 5, 237-246.

Connell, J. H. (1978), Diversity in tropical rain forest and coral reefs. Science, 199, 1302-10.

Finegan, B. (1984), Forest succession. Nature, 312, 109-114.

Fortney, R. H.; Benedict, M.; Gottgens, J. F.; Walters, T. L.; Leady, B. S. and Rentch, J. (2004), Aquatic plant community composition and distribution along an inundation gradient at two ecologically-distinct sites in the Pantanal region of Brazil. Wetl. Ecol. Manag., 12, 575-585.

Gleason, H. A. (1927), Further views on the successinconcept. Ecology, 8, 299-326.

Grime, J. P. (1977), Evidence for existence of three primary strategies in plants and its relevance to ecological and evolutionary theory. Am. Nat. 111, 1169-1194.

Grime, J. P. (1979), Plant strategies and vegetation process. London: John Wiley and Sons Ltd.

Junk, W. J.; Bayley, P. B. and Sparks, R. E. (1989), The flood pulse concept in river-floodplain systems. InDodge, D. P.(Ed.). Proc. Intern. Large River Symp. (LARS) Can. Spec. Publ. Fish. Aquat. Sci. 106, 11027.

Junk, W. J. and Piedade, M. T. F. (1997), Plant life in floodplain with special reference to herbaceous plants. In: Junk, W. J. (Ed.). The Central Amazon Floodplain: Ecology of a Pulsing System. SpringVerlag, Berlin. pp.147-85.

Londo, G. (1974), Successive mapping of the dune slack vegetation. Vegetatio, 29, 51-61.

Miles, J. (1979), Vegetation Dynamics. London, Chapman and Hall.

Dam on physical environment of the downstream floodplain. In-Thomaz, S. M.; Agostinho, A. A. and
Hahn, N. S. (Eds.). The Upper Paraná River and its Floodplain: Physical Aspects, Ecology and Conservation. Backhuys, Leiden. pp 27-50.

Thomaz, S. M.; Pagioro, T. A.; Bini, L. M.; Roberto, M. C. and Rocha, R. R. A. (2004), Limnological characterization of the aquatic environments and the influence of hydrometric levels. In-Thomaz, S. M.; Agostinho, A. A. and Hahn, N. S. (Eds.). The Upper Paraná River and its Floodplain: Physical Aspects, Miles, J. (1991), Vegetation succession: past and present perceptions. In: Gray, A. J.; Crawley, M. J. and Edwards, P. J. (Eds.). Colonization, Succession and Stability. Oxford, London: Blackwell Scietific Publications. pp. 1-29.

Neiff, J. J. (1990), Ideas para la interpretacion ecológica del Paraná. Interciencia 15, 424-41.

Pott, V. J. and Pott, A. (2000), Plantas aquáticas do Pantanal. Embrapa. Centro de Pesquisas Agropecuárias do Pantanal, Corumbá, Mato Grosso do Sul.

Souza-Filho, E. E.; Rocha, P. C.; Comunello, E. and Stevaux, J. C. (2004), Effects of the Porto Primavera Ecology and Conservation. Backhuys, Leiden. pp. 75-102

Thomaz, S. M.; Bini, L. M. and Bozelli, R. L. (2007). Floods increase similarity among aquatic habitats in river-floodplain systems. Hydrobiologia, 579, 1-13.

van der Valk, A. G. (1981), Succession in wetlands: a gleasonian approach. Ecology, 62(3), 688-696.

Received: June 09, 2005; Revised: July 27, 2007; Accepted: May 29, 2008. 